Krzysztof Tymicki

Instytut Statystyki i Demografii

Szkoła Główna Handlowa w Warszawie

krzysztof.tymicki@sgh.waw.pl

\title{
ZAMIERZENIA PROKREACYJNE A MOŻLIWOŚĆ ICH REALIZACJI W KONTEKŚCIE CZYNNIKÓW BIOLOGICZNYCH ${ }^{1}$
}

\section{WPROWADZENIE}

Spadek dzietności, jaki dokonał się w drugiej połowie XX wieku, właściwy przemianom opisywanym przez teorię drugiego przejścia demograficznego, jest jednym z głównych obszarów zainteresowania badaczy zajmujących się przemianami reprodukcji ludności. Istotnym mechanizmem odpowiedzialnym za spadek dzietności jest odraczanie decyzji prokreacyjnych, a co za tym idzie wzrost średniego wieku rodzenia pierwszego dziecka. Przyczyny tego zjawiska zostały dosyć dobrze rozpoznane i opisane przez demografów, co pozostaje w kontraście do zdecydowanie mniejszej liczby opracowań poświęconych konsekwencjom odraczania przez kobiety decyzji prokreacyjnych. Stąd głównym celem niniejszego artykułu jest opisanie, w jaki sposób odraczanie przez kobiety decyzji prokreacyjnych i towarzyszący temu spadek płodności mogą wpływać na możliwość realizacji intencji prokreacyjnych, dzietność zrealizowaną oraz obserwowaną dzietność. Pojęcie płodności oznacza przy tym zdolność do poczęcia oraz donoszenia płodu i może być stosowane wymiennie z pojęciem potencjału prokreacyjnego ${ }^{2}$.

W pierwszej części artykułu analizowane są relacje między dzietnością planowaną a zrealizowaną $\mathrm{w}$ krajach charakteryzujących się niskimi współczynnikami dzietności i wysokim średnim wiekiem rodzenia pierwszego dziecka. Druga część

1 Tekst powstał w ramach grantu pt. „Przemiany płodności w Polsce w latach 1945-2010 w kontekście efektu tempa i ilości: perspektywa mikro i makro" finansowanego przez MNiSW.

2 Wykorzystane w tekście pojęcie płodności jest bliższe terminowi 'fecundity' oznaczającemu zdolność do poczęcia i donoszenia płodu niż pojęciu 'fertility', które dotyczącemu urodzeń żywych w określonej populacji. 
tekstu koncentruje się na definicji najważniejszych pojęć oraz przedstawia teoretyczną perspektywę wpływu zmian płodności według wieku na możliwość realizacji zamierzeń prokreacyjnych. W części trzeciej przedstawione są analizy mające na celu określenie dynamiki zmian płodności kobiet i jej związku z możliwością realizacji zamierzeń prokreacyjnych.

Analizy te zostały przeprowadzone na podstawie danych badania ankietowego „Rodziny, Generacje i Płeć Kulturowa” (GGS-PL) zrealizowanego w Instytucie Statystyki i Demografii SGH (Kotowska i Jóźwiak 2011). Podsumowanie i dyskusja rezultatów zawarte w części ostatniej pozwalają odnieść uzyskane wyniki do szerszego kontekstu obejmującego, między innymi, zjawisko bezdzietności.

\section{DZIETNOŚĆ PLANOWANA I DZIETNOŚĆ ZREALIZOWANA: CHARAKTERYSTYKA RELACJI}

Głównym wątkiem rozważań jest możliwość realizacji zamierzeń prokreacyjnych w związku z opóźnianiem rozpoczęcia starań o pierwsze dziecko. Pojęcie zamierzeń prokreacyjnych definiowane jest jako deklaracja odnośnie do planowanej łącznej liczby potomstwa, którą respondent lub respondentka planuje osiągnąć w życiu. Alternatywnie, zamierzenia prokreacyjne mogą być definiowane jako deklaracje dotyczące planów krótkookresowych. W tym przypadku deklaracje dotyczą tego, czy respondent lub respondentka planuje mieć dzieci w określonym okresie rozpoczynającym się w momencie przeprowadzenia wywiadu ${ }^{3}$. Odpowiedzi respondentów na tak postawione pytania będą uzależnione od wielu zmiennych bezpośrednio i pośrednio wypływających na możliwość poczęcia i urodzenia dziecka, do których między innymi należą: liczba posiadanych dzieci w momencie przeprowadzania wywiadu, wiek respondenta, posiadanie partnera, stan zdrowia.

Z punktu widzenia zmian płodności i ich wpływu na dzietność zrealizowaną, kluczowa jest analiza zamierzeń prokreacyjnych osób, które nie posiadają dzieci, gdyż bezdzietność niedobrowolna może wpływać na ogólny poziom dzietności obserwowany $\mathrm{w}$ populacji. Jak wynika $\mathrm{z}$ badań sondażowych przeprowadzonych w Europie, bezdzietni respondenci w wieku od 20 do 28 lat najczęściej deklarują chęć posiadania dwójki dzieci (Testa 2012). Podobny rezultat otrzymano, analizując dane z badania GGS-PL, gdzie blisko 70\% respondentów bezdzietnych w momencie badania chciało posiadać dwoje dzieci (Kotowska i Jóźwiak 2011, Mynarska 2011).

Biorąc pod uwagę deklaratywny charakter odpowiedzi na pytanie o intencje prokreacyjne, liczba dzieci, jaką respondenci chcieliby mieć, jest na ogół wyższa od dzietności zrealizowanej mierzonej za pomocą ogólnego współczynnika dzietności. Wynika to nie tylko $\mathrm{z}$ deklaratywnego charakteru odpowiedzi na pytanie o inten-

3 W badaniu GGS-PL respondenci byli pytani o to, czy planują mieć dziecko w ciągu najbliższych 3 lat. 
cje prokreacyjne. Złożony charakter relacji między dzietnością planowaną a zrealizowaną sprawia, iż różnice te przypisywane są oddziaływaniu wielu czynników. Zalicza się do nich zarówno ogólny spadek poziomu dzietności (opisywany przez teorię drugiego przejścia demograficznego), jak i zawyżone intencje prokreacyjne (Toulemon i Testa 2005). Zawyżone intencje prokreacyjne mogą wynikać z czynników normatywnych, które każą postrzegać model rodziny z dwójką dzieci jako „właściwy”, a także z oczekiwań co do roli dzieci w przyszłości, gdy rodzice będą starzy (zabezpieczenie na starość), czy wreszcie realizacji indywidualnych preferencji partnerów (na przykład rozbieżnych preferencji rodziców w odniesieniu do płci dziecka). Różnice między dzietnością planowaną a zrealizowaną przypisuje się także wpływowi czynników ekonomicznych i instytucjonalnych (niskie finansowe wsparcie rodziny, dostępność opieki nad dziećmi w wieku 0-6 lat, sytuacji na rynku pracy - zatrudnienie, powrót na rynek pracy, możliwość godzenia pracy zawodowej i macierzyństwa), a także konkurencji między liczbą potomstwa a zaspokajaniem aspiracji materialnych gospodarstw domowych (Régnier-Loilier i Vignoli 2011, Sobotka 2007, Toulemon i Testa 2005).

Różnice między dzietnością zrealizowaną a planowaną nabierają szczególnego znaczenia w populacjach charakteryzujących się niską dzietnością, w których decyzja o posiadaniu kolejnego (drugiego) dziecka może mieć wpływ na to, czy płodność populacji będzie zbliżać się do poziomu gwarantującego prostą zastępowalność pokoleń, czy też raczej będzie utrzymywać się na niskim poziomie (Kohler i in. 2002). Dzietność niższa od planowanej i wynikający z niej spadek wartości miar płodności obserwowanych na poziomie makro tłumaczony jest najczęściej wzrostem średniego wieku rodzenia dzieci, co określane jest jako efekt tempa, oraz zmiany liczby urodzonych dzieci, co określane jest jako efekt ilości (Bongaarts i Feeney 1998). Rezygnacja z rodzenia kolejnych dzieci, a także systematyczny wzrost średniego wieku rodzenia dzieci, wywołany przede wszystkim przez wzrost wieku rodzenia pierwszego dziecka, są głównymi źródłami obserwowanego spadku dzietności zarówno w ujęciu wzdłużnym, jak i poprzecznym.

W demograficznych analizach przemian wzorca płodności wykorzystuje się schemat badawczy, który opiera się na badaniu wpływu czynników społecznych i ekonomicznych na efekt tempa oraz efekt ilości. Co więcej zakłada się, iż może występować „odzyskanie” (recuperation) urodzeń odroczonych na skutek opóźniania wieku rodzenia pierwszego dziecka poprzez wzrost płodności w starszych grupach wieku. Jednak pełne odzyskanie urodzeń odroczonych na skutek opóźniania wieku urodzenia pierwszego dziecka oznaczałoby, iż możliwe jest osiągnięcie dzietności planowanej nawet w sytuacji, w której kobiety późno decydują się na macierzyństwo (Sobotka i in. 2011). W konsekwencji osiągnięcie dzietności planowanej byłoby niezależne od wieku matki w chwili urodzenia pierwszego dziecka, czyli de facto pomijałoby wpływ zmian płodności na możliwość posiadania potomstwa. Uwzględniając wiedzę dotyczącą zmian płodności kobiet, można uznać, iż założenie to nie jest realistyczne. Stąd istotne jest określenie w jakim stopniu, a co ważniejsze w jakim 
wieku spadek płodności może w istotny sposób wpłynąć na możliwość realizacji zamierzeń prokreacyjnych.

\section{WPŁYW ZMIAN PŁODNOŚCI NA MOŻLIWOŚĆ REALIZACJI ZAMIERZEŃ PROKREACYJNYCH}

Założenie, iż możliwe jest całkowite odzyskanie urodzeń odroczonych wskutek przesuwania decyzji o urodzeniu pierwszego dziecka do późniejszego wieku i urodzenie zaplanowanej liczby dzieci, może być trafne jedynie w przypadku, gdy decyzja o rozpoczęciu starań o dziecko nie zapada zbyt późno. Decyzja o tym, kiedy zacząć starać się o dziecko, może mieć fundamentalne znaczenie dla możliwości zajścia w ciążę i urodzenia zdrowego dziecka, gdyż wraz z wiekiem spadają bowiem szanse na poczęcie i urodzenie dziecka (Beets i in. 1994). Zasadne jest więc przypuszczenie, że po przekroczeniu pewnego wieku kobiety nie będą w stanie osiągnąć pożądanej liczby dzieci ze względu na zbyt duży spadek płodności. Istotne jest zatem określenie wieku, w którym spadek płodności może mieć istotny wpływ na możliwość realizacji zamierzeń prokreacyjnych.

W anglojęzycznej literaturze przedmiotu płodność, zwana także potencjałem prokreacyjnym, określana jest pojęciem fecundity (Wood 1989). Pojęcie to oznacza prawdopodobieństwo zajścia $\mathrm{w}$ ciążę $\mathrm{w}$ określonym czasie przy założeniu regularnego współżycia przy braku stosowania jakiejkolwiek formy antykoncepcji (O’Connor i in. 1998). Szereg badań wskazuje na to, iż w przypadku kobiet odraczanie decyzji o rozpoczęciu starań o dziecko i związany z tym spadek potencjału prokreacyjnego wraz $\mathrm{z}$ wiekiem przekłada się na większe problemy z poczęciem i urodzeniem dziecka. W przypadku mężczyzn spadek potencjału prokreacyjnego jest zdecydowanie mniejszy (O'Connor i in. 1998, Sartorius i Nieschalg 2010). Stąd opóźnianie wieku rozpoczęcia starań o pierwsze dziecko może posiadać konsekwencje zarówno medyczne w postaci obniżonej płodności (na poziomie jednostki), jak i demograficzne w postaci spadku współczynników dzietności (na poziomie populacji) (Schmidt i in. 2012). Jak sugerują niektórzy autorzy (Bongaarts 2002, Sobotka i in. 2005), proces odraczania decyzji prokreacyjnych w krajach Europy Zachodniej dobiega końca i nie należy spodziewać się dalszego wzrostu średniego wieku urodzenia pierwszego dziecka. Nadal jednak pozostaje pytanie, czy przy obecnie obserwowanym średnim wieku rodzenia pierwszego dziecka spadek potencjału prokreacyjnego jest na tyle duży, iż może prowadzić do problemów z zajściem w ciążę, a tym samym wpływać na ogólny poziom dzietności. Jest to szczególnie ważne $\mathrm{w}$ krajach o niskiej płodności, w których odraczanie tego wieku jeszcze trwa. Do tej grupy należy Polska. Ponadto, należy przypuszczać, że kobiety z niektórych grup społecznych (np. z wyższym wykształceniem) decydują się na rozpoczęcie starań o dziecko później niż ogół populacji, a zatem spadek potencjału prokreacyjnego może odegrać tam istotniejszą rolę. Stąd szcze- 
gólnego znaczenia nabiera ustalenie wieku, w którym obserwujemy znaczący spadek płodności.

Jak wspomniano, cechą określającą płodność w przebiegu życia kobiet od momentu osiągnięcia dojrzałości płciowej do menopauzy są zmiany prawdopodobieństwa zapłodnienia. Zmiany te mają charakter nieliniowy, gdyż kobiety osiągają maksimum potencjału prokreacyjnego około wieku 20-22 lat, po czym następuje stopniowy spadek możliwości zapłodnienia aż do wieku w którym osiągana jest menopauza (Wood 1989: 77). Systematyczny spadek prawdopodobieństwa zapłodnienia od przekroczenia wartości maksymalnej jest związany głównie z wpływem starzenia się organizmu na produkcję komórek jajowych (O'Connor i in. 1998). Z perspektywy relacji między płodnością a możliwością realizacji zamierzeń prokreacyjnych w populacjach współczesnych krajów rozwiniętych istotne znaczenie ma oddzielenie procesu reprodukcyjnego starzenia się od procesu starzenia się innych organów i całego organizmu. Systematyczne wydłużanie się życia jako konsekwencja przemian cywilizacyjnych doprowadziło do sytuacji, w której duża część populacji kobiet cieszy się dobrym zdrowiem przy znacznie obniżonej płodności. Inaczej było w populacjach o niskiej oczekiwanej długości życia, gdzie starzenie reprodukcyjne było ściśle związane z procesem starzenia się całego organizmu. W konsekwencji w populacjach współczesnych przeciętny wiek rozpoczęcia prokreacji przesunął się do wieku, który nie był możliwy do osiągnięcia w populacjach historycznych z uwagi na wysoką umieralność i zdecydowanie niższą oczekiwaną długość życia. Negatywną konsekwencją tego procesu w populacjach współczesnych jest rozpoczynanie starań o dziecko w wieku, w którym płodność daleka jest od wartości maksymalnej (Kaplan i in. 2000). Należy też zwrócić uwagę na to, iż konsekwencją wydłużania się życia jest bardzo długi i charakterystyczny wyłącznie dla gatunku ludzkiego okres post-menopauzalny, który jest rezultatem wspomnianej wyżej dywergencji między starzeniem się organizmu a starzeniem się funkcji reprodukcyjnych (Hawkes 2003, Hill i Hurtado 1991, Shanley i Kirkwood 2001).

Rozważania dotyczące procesu reprodukcyjnego starzenia się nabierają znaczenia w kontekście przemian wzorca dzietności obserwowanego w trakcie drugiego przejścia demograficznego, który charakteryzuje się wzrostem średniego wieku rodzenia pierwszego dziecka. Porównując średni wiek rodzenia pierwszego dziecka w okresie pierwszego przejścia demograficznego oraz drugiego przejścia demograficznego można zaobserwować wspomnianą wyżej rozbieżność między optymalnym z biologicznego punktu widzenia a faktycznym przeciętnym wiekiem rodzenia pierwszego dziecka. W okresie poprzedzającym drugie przejście demograficzne średni wiek rodzenia pierwszego dziecka przypadał mniej więcej w okresie maksimum wartości potencjału prokreacyjnego (około 20-23 lata), podczas gdy w 2011 roku średni wiek rodzenia pierwszego dziecka w krajach OECD wyniósł około 28 lat ${ }^{4}$.

4 OECD Family Database, zasób internetowy, http://www.oecd.org/els/soc/ (data dostępu: wrzesień 2013). 
Zgodnie z modelem teoretycznym płodność kobiet stanowi w wieku 28 lat około 80\% wartości maksymalnej (Wood 1989: 77). Dla porównania kobiety w wieku 35 lat dysponują jedynie około $60 \%$ maksymalnej wartości potencjału prokreacyjnego.

Rosnąca rozbieżność między wiekiem o najwyższym potencjale prokreacyjnym a momentem w przebiegu życia, w którym kobiety decydują się na rozpoczęcie starań o dziecko może sprawiać, iż będzie im trudniej zajść w ciążę, a poczęcie dziecka będzie trwało dłużej, niż ma to miejsce w przypadku kobiet znajdujących się u szczytu możliwości prokreacyjnych (Bianchi i Campana 1994, te Velde i Pearson 2002).

Rozważania dotyczące wpływu spadku potencjału prokreacyjnego na dzietność zrealizowaną dopiero niedawno stały się przedmiotem zainteresowania demografów (ESHRE 2005, Leridon 2004, Schmidt i in. 2012, te Velde i in. 2012). Badania te skupiają się na rozpoznaniu demograficznych i biologicznych konsekwencji reprodukcyjnego starzenia, takich jak wzrost udziału par nie mogących posiadać dziecka z przyczyn biologicznych, wpływ odraczania decyzji o rozpoczęciu starań o dziecko na prawdopodobieństwo zapłodnienia, czy możliwość kompensowania spadku płodności za pomocą metod wspomagania zapłodnienia. Analizy te wskazują jasno, iż opóźnianie wieku rozpoczęcia starań o dziecko może prowadzić do trudności w realizacji zamierzeń prokreacyjnych głównie z uwagi na spadek płodności wraz z wiekiem (Liu i Case 2011, O’Connor i in. 1998, Van Geloven i in. 2013). Biorąc pod uwagę czynniki biologiczne (ilość wytwarzanych pęcherzyków Graffa oraz proporcję słabej jakości oocytów), optymalny wiek poczęcia dziecka przypada na wiek między 18 a 31 rokiem życia, choć i w tym interwale obserwujemy spadek liczby wytwarzanych pęcherzyków Graffa i rosnącą proporcję słabej jakości oocytów (Liu i Case 2011: 1168). Okres najintensywniejszego spadku płodności przypada między 32-tym a 42-tym rokiem życia. Wtedy gwałtownie obniża się liczba produkowanych pęcherzyków Graffa przy stale rosnącym udziale słabej jakości oocytów. Wreszcie, po przekroczeniu wieku około 42 lat spadek płodności jest tak wyraźny, iż prawdopodobieństwo zapłodnienia jest bardzo niskie aż do pojawienia się nieregularności w cyklu menstruacyjnym i menopauzy.

Jak konkludują autorzy cytowanych badań, zaobserwowane prawidłowości biologiczne wskazują, iż wiek około 35 lat staje się wartością graniczną, po której przekroczeniu okres konieczny do zapłodnienia może zdecydowanie wydłużyć się lub mogą pojawić się pierwsze symptomy obniżonej płodności, trudności z poczęciem dziecka, a tym samym problemy z realizacją zamierzeń prokreacyjnych.

Ze względu na opóźnianie przeciętnego wieku rozpoczęcia starań o dziecko oraz tempo reprodukcyjnego starzenia się kobiet we współczesnych populacjach krajów rozwiniętych, autorzy uważają za istotne podjęcie działań w celu informowania opinii publicznej o biologicznych konsekwencjach późnego macierzyństwa (Liu i Case 2011).

Spadek potencjału prokreacyjnego wraz z wiekiem może zatem wpływać na tzw. czas oczekiwania na ciążę, czyli interwał między rozpoczęciem świadomych starań 
o dziecko a poczęciem. Interwał ten jest istotnym elementem wzorca reprodukcji zarówno w populacjach o płodności naturalnej, jak i kontrolowanej. W populacjach charakteryzujących się płodnością naturalną czas oczekiwania na ciążę stanowi jeden z bezpośrednich determinantów dzietności (Bongaarts 1978, 1990). W społecznościach współczesnych charakteryzujących się prawie pełną kontrolą nad procesem reprodukcji, zdecydowanie niższą dzietnością a zarazem wyższym wiekiem rozpoczęcia starań o pierwsze dziecko, znaczenie czasu oczekiwania na ciążę będzie nieco odmienne. Będzie głównie dotyczyło tego, czy para w ogóle będzie mogła posiadać potomstwo oraz czy uda się zrealizować zamierzenia prokreacyjne.

Biorąc pod uwagę powyższe rozważania, zmiany indywidualnych decyzji dotyczących tego, kiedy rozpocząć starania o dziecko, mogą mieć fundamentalne znaczenie dla możliwości zajścia w ciążę i urodzenia zdrowego dziecka (Beets i in. 1994). Stąd analizy nakierowane na poznanie biologicznych konsekwencji późnego macierzyństwa mogą pomóc $\mathrm{w}$ zrozumieniu zarówno tego, czy w przypadku kobiet w krajach rozwiniętych obserwujemy problemy z poczęciem dziecka, a także czy w przyszłości możemy spodziewać się spadku ogólnego poziomu dzietności z uwagi na rosnące problemy z zachodzeniem w ciążę. Analiza taka umożliwia zatem uwypuklenie wpływu czynników biologicznych na możliwość realizacji zamierzeń prokreacyjnych (Schmidt i in. 2012). Późne rozpoczęcie starań o dziecko może prowadzić do późnej diagnozy zaburzeń płodności i pozostawić mniej czasu na ewentualne leczenie lub zastosowanie metod wspomagania poczęcia (Leridon 2004).

\section{ZMIANY PŁODNOŚCI A MOŻLIWOŚĆ REALIZACJI ZAMIERZEŃ PROKREACYJNYCH}

Omówione powyżej zmiany płodności kobiet wraz z wiekiem znajdują swoje odzwierciedlenie w oficjalnie stosowanej terminologii. W przypadku skrajnym, gdy mówimy o osobach, które nie mogą posiadać dzieci z przyczyn biologicznych, używamy pojęcia bezpłodności, która oznacza trwałą niezdolność do posiadania potomstwa. W pozostałych przypadkach możemy mówić o niepłodności. Zgodnie z definicją zaproponowaną przez Światową Organizację Zdrowia (ang. World Health Organisation, WHO) należy ją rozumieć jako sytuację, w której nie jest możliwe poczęcie dziecka (zajście w ciążę), utrzymanie ciąży lub urodzenie żywego dziecka pomimo rocznego współżycia seksualnego z przeciętną częstotliwością 3-4 stosunków tygodniowo, bez stosowania jakichkolwiek środków antykoncepcyjnych (Zegers-Hochschild i in. 2009).

Rozważając wpływ reprodukcyjnego starzenia się na stopniowy spadek możliwości realizacji zamierzeń prokreacyjnych musimy mówić o rosnącym zagrożeniu niepłodnością, które przejawia się wydłużaniem okresu od momentu rozpoczęcia starań o dziecko aż do poczęcia przy założeniu regularnego współżycia bez wykorzystania metod zapobiegania ciąży (Gnoth i in. 2005, Habbema i in. 2004, Jenkins i in. 2004). 
Według tak przyjętego sposobu pomiaru (Gnoth i in. 2005) i zakładając regularne współżycie w ciągu dni płodnych, w przypadku około $80 \%$ par powinno dojść do zapłodnienia w ciągu 6 miesięcy, a pozostałe $20 \%$ par może wykazywać nieznaczny stopień niepłodności. Po okresie 12 miesięcy ten drugi odsetek powinien kształtować się w granicach $10 \%$, a po 48 miesiącach będziemy mieć do czynienia z około 5\% par bezpłodnych. Tym samym ograniczona płodność będzie przejawiać się wydłużeniem interwału między rozpoczęciem starań o dziecko a zajściem w ciążę.

Pomiar zmian potencjału prokreacyjnego opiera się zatem na pozyskaniu informacji o długości okresu od momentu rozpoczęcia świadomych starań o dziecko (rezygnacji z kontroli urodzeń przy jednoczesnym regularnym współżyciu) do momentu zapłodnienia (a ściślej zajścia w ciążę i identyfikacji tego faktu). W literaturze proponuje się określenie wspomnianego interwału jako tzw. czasu oczekiwania na ciążę ${ }^{5}$ (Jesen i in. 2005, Joffe 2005, Olsen $i$ in. 1998).

Zaproponowany sposób pomiaru pozwala łatwo określić przypadki, w których dochodzi do wydłużenia się interwału ze względu na obniżoną płodność lub niepłodność. Należy tu zwrócić uwagę na fakt, iż pomiar ten jest rzetelny jedynie w odniesieniu do par świadomie starających się o poczęcie dziecka, co zakłada brak stosowania jakiejkolwiek metody zapobiegania ciąży oraz podjęcie regularnego współżycia. Jedynie wtedy możemy mieć do czynienia z wyizolowaniem zmian płodności według wieku oraz ich wpływu na długość interwału koniecznego do poczęcia dziecka. W celu pomiaru tego interwału najczęściej wykorzystuje się badania retrospektywne, w których respondenci proszeni są o określenie liczby cykli menstruacyjnych lub miesięcy od momentu rozpoczęcia starań o dziecko aż do zapłodnienia dla każdej ciąży (Baird i in. 1991, Joffe i in. 2005). Pytanie to umożliwia ocenę zmian płodności par wraz z wiekiem oraz sprawdzenie, czy długość interwałów koniecznych do zapłodnienia odpowiada wspomnianym wcześniej kategoriom przyjętym przez WHO (ORC 2004). Podstawową przewagą retrospektywnego podejścia do badania czasu oczekiwania na ciążę jest łatwość zebrania danych w odróżnieniu od na przykład metody prospektywnej, która jest długotrwała i która czasem wiążę się z rezygnacją respondentów z udziału w badaniu. Dodatkowe pytania w standardowym kwestionariuszu mierzącym czas oczekiwania na ciążę dotyczą tego, czy partnerzy mają zdiagnozowaną bezpłodność, czy stosowali jakikolwiek sposób wspomagania zapłodnienia lub antykoncepcję.

Metodyka pomiaru za pomocą kwestionariusza retrospektywnego była wykorzystywana w wielu badaniach. Pomimo problemów związanych z jej precyzją autorzy wskazują, iż stanowi ona jedyne narzędzie, za pomocą którego można zmierzyć wpływ spadku płodności na możliwość realizacji zamierzeń prokreacyjnych na relatywnie dużych próbach losowych (Baird i in. 1991, Dick i in. 2003, Jensen i in. 2005a, b).

5 W literaturze anglojęzycznej wykorzystywane są następujące pojęcia: Waiting Time to Pregnancy (WTP), Time to Pregnancy (TtP) oraz Cycles to Pregnancy (CtP) (Joffe 2005, Olsen i in. 1998). 
Główne problemy dotyczące pomiaru czasu oczekiwania na ciążę wynikające z wykorzystania podejścia retrospektywnego polegają na trudnościach $\mathrm{z}$ dokładnym określeniem przez respondentów liczby miesięcy (lub cykli menstruacyjnych) potrzebnych do poczęcia dziecka. Jak wynika z przeprowadzonych analiz wiarygodności danych dotyczących czasu oczekiwania na ciążę, respondenci nie mieli większych problemów z przypomnieniem sobie tych zdarzeń nawet do 20 lat wstecz (Joffe i in. 2005). Natomiast w przypadku braku pewności respondenci byli skłonni do grupowania odpowiedzi w tzw. węzłach, na przykład,,około 6 miesięcy" lub „około roku”. Należy także zwrócić uwagę na odpowiedni dobór respondentów, którzy mają udzielić odpowiedzi na pytania dotyczące czasu oczekiwania na ciążę. $\mathrm{Z}$ punktu widzenia precyzji pomiaru, najwłaściwszym rozwiązaniem jest przeprowadzanie badania na populacji generalnej, to znaczy wśród par, które już posiadają dziecko, aktualnie spodziewają się dziecka, a także które dopiero starają się o dziecko.

Inny problem związany $\mathrm{z}$ pomiarem interwału między rozpoczęciem starań o dziecko a poczęciem dotyczy kwestii planowania ciąży. W przyjętej metodyce zakłada się, iż staranie się o dziecko jest procesem zaplanowanym w odróżnieniu od poczęcia będącego rezultatem przypadku (przy nieskutecznym zapobieganiu ciąży lub jego braku) i nie związanego z planami prokreacyjnymi par. Przyjmuje się, iż takie przypadkowe poczęcie może być rezultatem wysokiej płodności, a brak stosowania metod zapobiegania ciąży przy jednoczesnym braku intencji prokreacyjnych może być związane z wiedzą lub przekonaniem pary o niskiej płodności bądź niepłodności (Olsen i in. 1998). Mając na uwadze dokładność pomiaru zmian płodności sugeruje się, by czas oczekiwania na ciążę był mierzony jedynie w przypadku ciąż pierwszych. Postulat ten motywowany jest tym, iż wiek rozpoczęcia starań o dziecko, a tym samym przyszłe macierzyństwo, będzie miało kluczowe znaczenie dla dalszych decyzji prokreacyjnych. Dodatkowo w przypadku starań o kolejne dziecko mamy do czynienia z parami płodnymi, co do których zachodzi mniejsza obawa, iż mogą mieć problemy z poczęciem dziecka. Ważne jest także, iż pary starające się o kolejne dziecko mają zazwyczaj krótszy czas oczekiwania na ciąże niż pary starające się o pierwsze dziecko (Boldsen i Schaumburg 1990).

\section{WYNIKI BADAŃ: CZAS OCZEKIWANIA NA CIĄŻĘ W BADANIU GGS-PL 2011}

Przedstawiona metodyka pomiaru czasu oczekiwania na ciążę jako interwału między świadomym rozpoczęciem starań o dziecko a poczęciem została wykorzystana w pierwszej fali badania GGS-PL zrealizowanego przez Instytut Statystyki i Demografii SGH w 2011 roku (Kotowska i Jóźwiak 2011). Podstawowym celem analizy było określenie, czy obserwujemy wydłużanie się czasu oczekiwania na ciążę wraz ze wzrostem wieku kobiet objętych badaniem, a także czy osoby odra- 
czające decyzję o posiadaniu pierwszego dziecka mogą liczyć się z problemami z poczęciem wynikającymi z procesu reprodukcyjnego starzenia się.

Badanie zostało przeprowadzone za pomocą tradycyjnego wywiadu kwestionariuszowego. W celu zapewnienia reprezentatywności badania, próba główna została określona na 20 tys. Adresów i została wyodrębniona z zastosowaniem dwustopniowego schematu losowania. Dla województw liczebności prób zostały ustalone na podstawie metody pierwiastkowej. W obrębie województw zastosowane zostało losowanie warstwowe (warstwami były: gminy, miasta lub dzielnice w przypadku Warszawy). W pierwszym stopniu losowane były obwody spisowe (około 4 tysięcy obwodów), zaś w drugim stopniu adresy (średnio po 5 adresów w obwodzie), co dało wyjściową liczebność równą 20 tysięcy. W każdym z wylosowanych adresów ankieter przeprowadzał spis wszystkich osób zamieszkujących gospodarstwo domowe, ale wywiad był przeprowadzany tylko z jedną osobą w wieku 17-79 lat.

Moduł służący pomiarowi czasu oczekiwania na ciążę został włączony do działu 6 ankiety badania GGS-PL pt.: „Płodność”. W zamierzeniu dział ten miał na celu opisanie zachowań prokreacyjnych par, stosowania antykoncepcji, czasu oczekiwania na ciążę oraz przyszłych zamierzeń prokreacyjnych. Pytania wykorzystane do pomiaru są adaptacją pytań zawartych w kwestionariuszach opracowanych przez innych badaczy (Baird 1991, Joffe 2005, Olsen 1998). W dziale 6 zostały zawarte pytania dotyczące następujących kwestii:

- wiek inicjacji seksualnej,

- antykoncepcja (metody i stosowanie),

- problemy z płodnością (diagnoza, leczenie),

- czas oczekiwania na ciążę: deklarowana liczba cykli menstruacyjnych, które upłynęły od momentu rozpoczęcia świadomych starań o dziecko (dla par, które zrezygnowały ze stosowania antykoncepcji) oraz od momentu rozpoczęcia współżycia (dla par, które deklarowały nie stosowanie żadnej metody zapobiegania ciąży) do zajścia w ciążę,

- intencje prokreacyjne,

- ocena wpływu pojawienia się dziecka (kolejnych dzieci) na rozmaite aspekty życia,

- wpływ wybranych aspektów na decyzję o posiadaniu dziecka (kolejnych dzieci),

- oczekiwania rodziny i przyjaciół względem posiadania dzieci przez respondenta(kę).

Dział 6 ankiety GGS-PL adresowany był do respondentów obu płci w wieku co najwyżej 49 lat oraz do mężczyzn (niezależnie od wieku), których partnerka nie przekroczyła 49-tego roku życia. Biorąc pod uwagę ograniczenie nałożone na wiek respondentów a także fakt, iż do odpowiedzi na pytania zawarte w tym dziale kwalifikowali się respondenci, którzy rozpoczęli współżycie seksualne, pytania skierowano do 5359 osób. 849 osób, czyli około 15\%, odmówiło odpowiedzi na pytanie o rozpoczęcie współżycia seksualnego i dlatego osobom tym nie zadano pozostałych pytań zawartych w dziale. Ponadto sekwencja pytań zależała od tego, 
czy w momencie przeprowadzania ankiety respondentka lub partnerka respondenta była w ciąży. Jedynie 140 osób zakwalifikowanych do odpowiedzi wskazało, że spodziewają się dziecka, a 32 osoby określiły, że w chwili wywiadu kobieta „być może" spodziewa się dziecka. Z uwagi na to, że niektóre pytania do obu grup respondentów (zarówno spodziewających się dziecka, jak i niespodziewających się dziecka) były identyczne, a także biorąc pod uwagę niewielką liczbę respondentów spodziewających się dziecka, w miarę możliwości obie grupy były rozpatrywane łącznie. Grupa respondentów, których odpowiedzi poddano analizie, składała się z 1617 osób.

$\mathrm{Na}$ wstępie sprawdzono częstość wystąpienia bezpłodności wśród badanych respondentów. W badanej grupie w momencie wywiadu około $9 \%$ przyznało, że zdecydowanie lub prawdopodobnie nie mogą mieć dzieci (lub kolejnego dziecka) z przyczyn biologicznych. Około $6 \%$ respondentów wskazało, że ich partner lub partnerka nie mogą mieć dzieci z przyczyn biologicznych. Należy zwrócić uwagę, iż biologiczne przeszkody w posiadaniu dzieci znalazły potwierdzenie w badaniach medycznych jedynie w około 7\% przypadków. Rozkłady odpowiedzi na pytania dotyczące świadomości respondentów co do biologicznych możliwości posiadania potomstwa zostały przedstawione na rys. 1 i 2 .

Rys. 1. Rozkład odpowiedzi na pytanie: „Niektóre osoby nie mogą mieć dzieci z przyczyn biologicznych. Czy według Pana(i) może mieć Pan(i) dzieci?" (w \%)

Fig. 1. Responses to the question, "Some people are not able for having children due to biological reasons. Are you able for having children?"(in \%)

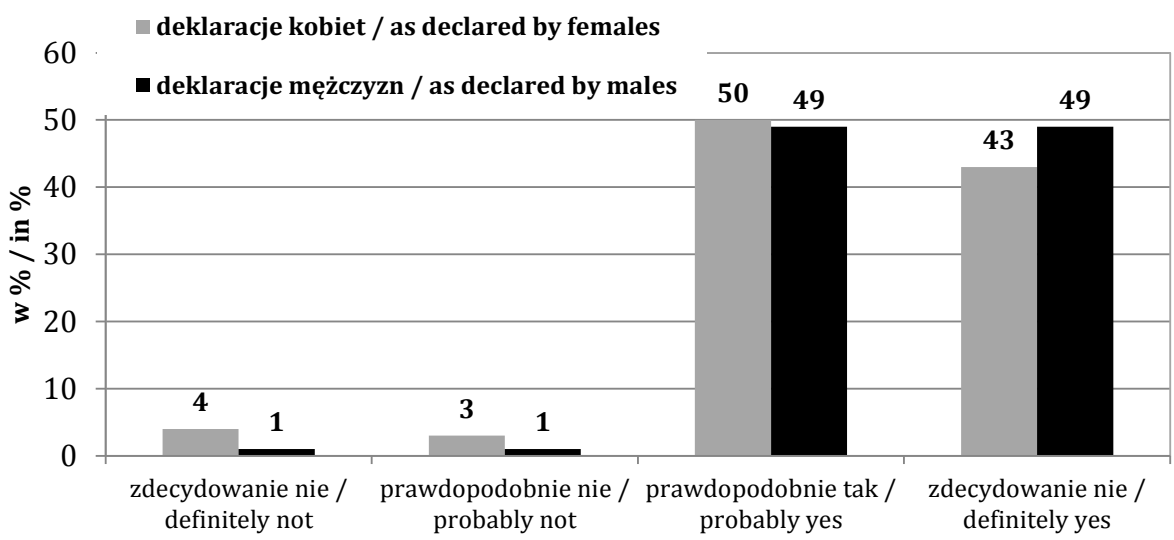

Źródło: opracowanie własne na podstawie badania GGS-PL.

Source: own elaboration based on the GGS-PL survey. 
Rys. 2. Rozkład odpowiedzi na pytanie: „Niektóre osoby nie mogą mieć dzieci z przyczyn biologicznych. Czy według Pan(i) Pana(i) partner/małżonek może mieć dzieci?” (w \%)

Fig. 2. Responses to the question, "Some people are not able for having children due to biological reasons. Are you partner is able for having children?" (in \%)

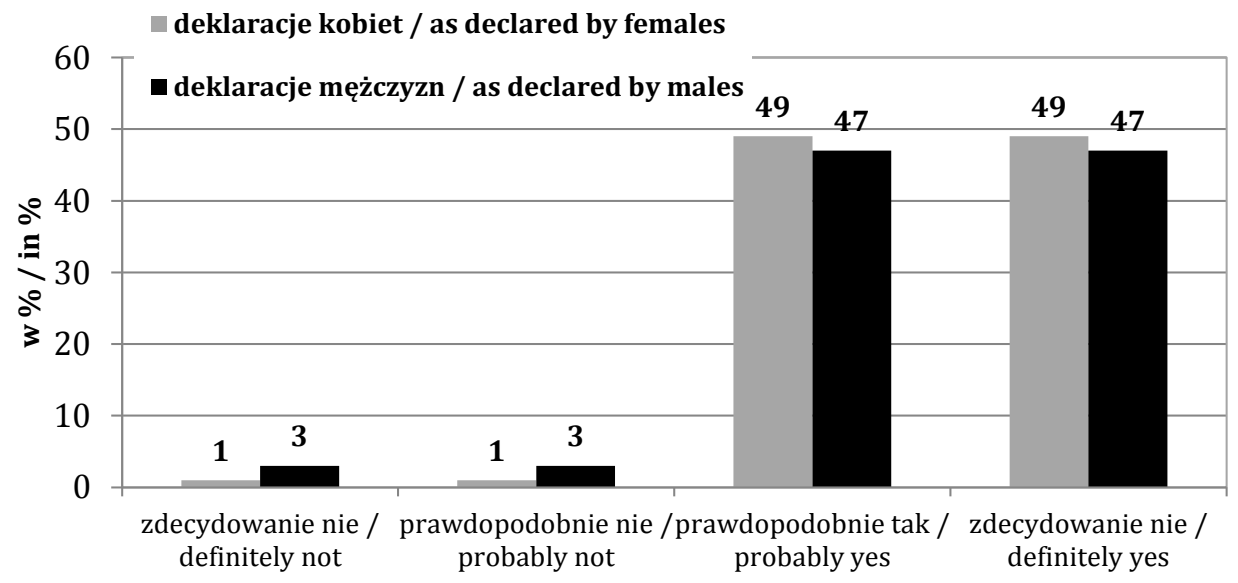

Źródło: opracowanie własne na podstawie badania GGS-PL.

Source: own elaboration based on the GGS-PL survey.

Kobiety zdecydowanie częściej niż mężczyźni deklarowały brak możliwości posiadania potomstwa z przyczyn biologicznych (łącznie ok. 7\% kobiet zadeklarowało, że zdecydowanie lub prawdopodobnie nie mogą posiadać dzieci z przyczyn biologicznych, podczas gdy analogiczny odsetek mężczyzn wyniósł ok. 2\%). Nie ma podstaw merytorycznych by sądzić, iż problemy z płodnością dotyczą częściej kobiet niż mężczyzn. Różnice te mogą wynikać z niechęci mężczyzn do przyznania przed ankieterem, iż w ich przypadku stwierdzono ograniczony potencjał prokreacyjny (w przypadku świadomości co do ograniczonej płodności) lub z ich niewiedzy o ewentualnej bezpłodności lub niepłodności. Innymi słowy, różnica ta może wynikać z faktu, iż to kobiety częściej poddają się badaniom pozwalającym określić ich płodność niż mężczyźni, a także mogą mieć mniejszą awersję do przyznania tego $\mathrm{w}$ wywiadzie. Wyniki te są zgodne z odpowiedziami na pytanie o to, czy respondenci posiadają wiedzę o biologicznej możliwości posiadania potomstwa przez partnera bądź partnerkę. Około $6 \%$ mężczyzn deklaruje, że ich partnerka zdecydowanie lub prawdopodobnie nie może mieć dzieci, podczas gdy analogiczny odsetek w przypadku deklaracji kobiet co do braku biologicznej możliwości posiadania potomstwa przez partnerów wynosi około $2 \%$. Zaobserwowana w próbie częstość wystąpienia niepłodności i bezpłodności na poziomie około 6-7\% jest zbliżona do wyników badań w innych populacjach (Karmaus i Juul 1999). 
Zamierzenia prokreacyjne a możliwość ich realizacji w kontekście czynników...

Kolejna część działu 6 ankiety GGS-PL poświęcona była stosowanym przez respondentów metodom antykoncepcji. Wśród respondentów niestarających się o dziecko i nieoczekujących dziecka w momencie badania 54\% zadeklarowało stosowanie jakiejkolwiek formy antykoncepcji. Najpowszechniej stosowaną metodą była prezerwatywa oraz pigułka antykoncepcyjna. W ankiecie zawarto również pytanie o to, czy mimo stosowania metod zapobiegania ciąży doszło do poczęcia. W założeniu to pytanie miało określić i doprecyzować nie tylko ewentualną niedoskonałość stosowanej metody, ale także ustalić, czy zajście w ciążę było przez parę planowane. W sytuacji takiej znalazło się 42 respondentów lub ich partnerów, czyli jedynie około 2\% badanej zbiorowości.

Jednym z głównych celów działu 6 ankiety był pomiar interwału między świadomym rozpoczęciem starań o dziecko a poczęciem (tzw. czas oczekiwania na ciążę). Łącznie na pytanie o czas oczekiwania na ciążę udzieliło odpowiedzi 1684 respondentów ${ }^{6}$. Rozkład czasu oczekiwania na ciążę dla zbiorowości badanych kobiet, którym udało się począć dziecko, przedstawiono na rys. 3.

Rys. 3. Rozkład czasu oczekiwania na pierwszą ciążę (interwał od momentu rozpoczęcia starań o dziecko do poczęcia) (w miesiącach)

Fig. 3. Waiting time to pregnancy (interval from onset of a deliberate attempt to conceive) (in months)

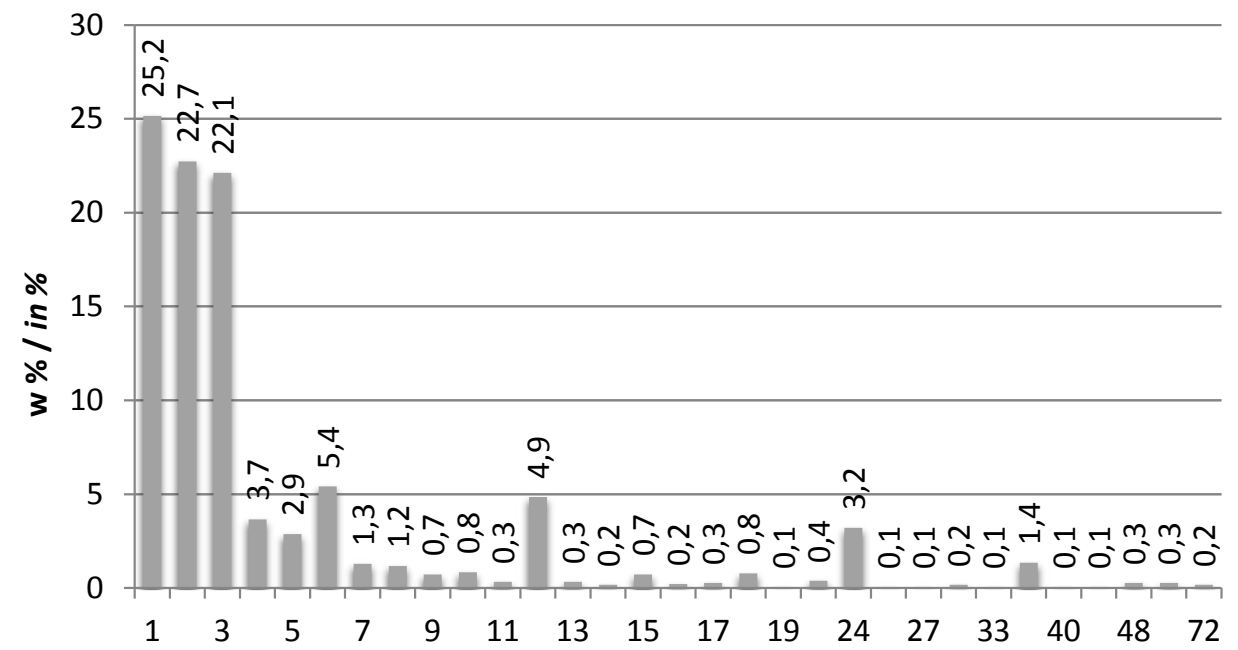

w miesiącach / in months

Źródło: opracowanie własne na podstawie badania GGS-PL.

Source: own elaboration based on the GGS-PL survey.

6 W dotychczasowych badaniach jest to największa ogólnopolska próba wykorzystana do badania potencjału prokreacyjnego. 
Około 70\% par poczyna dziecko w ciągu 3 pierwszych miesięcy (cykli menstruacyjnych) niezabezpieczonego współżycia (przy założeniu jego regularności). Odsetek ten jest zbieżny $\mathrm{z}$ wynikami badań przedstawionych $\mathrm{w}$ innych badaniach (Gnoth 2005, Jensen i in. 2005a, b). W przeprowadzonym badaniu jedynie 9\% par potrzebowało więcej niż rok na poczęcie dziecka. Odsetek ten może wynikać z tego, iż pary te miały obniżoną płodność, ale także może świadczyć o braku regularnego współżycia na przykład z powodu dłuższej nieobecności jednego z partnerów. Koncentracja odpowiedzi respondentów w okolicach 6 i 12 miesiąca nie wynika ze zwiększonej częstotliwości zapłodnień w tych momentach, a świadczy raczej o trudnościach respondentów z przywołaniem dokładnej długości interwału.

Analizując dane dotyczące czasu oczekiwania na pierwszą ciążę z polskiej edycji badania GGS-PL, należy zwrócić uwagę na dwie istotne kwestie. Po pierwsze, w bazie danych występują jedynie kobiety, którym udało się urodzić pierwsze dziecko. Wynika to ze sposobu konstrukcji pytań w ankiecie, a także faktu, iż z punktu widzenia celów badania istotne jest określenie czasu oczekiwania na ciążę osób płodnych. Po drugie, zmienną różnicującą czas oczekiwania na pierwszą ciążę jest wiek matki w momencie urodzenia pierwszego dziecka. Niestety nie było możliwe wykorzystanie wieku w momencie rozpoczęcia świadomych starań o dziecko z uwagi na zbyt małą liczbę przypadków, w których kobiety rozpoczynały starania po ukończeniu 35-ego roku życia.

W celu oszacowania wpływu wieku kobiet na interwał między świadomym rozpoczęciem starań o dziecko a poczęciem wykorzystano oszacowanie funkcji dożycia metodą Kaplana-Meiera. Metoda ta umożliwia określenie frakcji kobiet oczekujących na ciążę od momentu rozpoczęcia świadomych starań o dziecko, a oszacowanie funkcji dożycia ze względu na wiek kobiet pozwala dodatkowo stwierdzić, czy spadek płodności może mieć znaczący wpływ na długość czasu oczekiwania na ciążę i tym samym może utrudnić realizację zamierzeń prokreacyjnych. Wyniki analiz czasu oczekiwania na ciążę ze względu na wiek kobiety w momencie urodzenia pierwszego dziecka zostały przedstawione na rys. 4.

Porównując czas oczekiwania na ciążę, można zaobserwować znaczne zmiany ze względu na wiek matek ${ }^{7}$. Blisko $25 \%$ kobiet, które urodziły swoje pierwsze dziecko w wieku 35 lat i więcej musiały czekać na ciążę rok lub dłużej, podczas gdy analogiczny odsetek wśród kobiet młodszych, w wieku 25-29 lat wyniósł jedynie około 4-5\%. Warto zwrócić uwagę, iż funkcja dożycia dla matek w wieku poniżej 24 lat i w wieku 25-29 lat nie różnią się między sobą w istotny sposób. Istotne statystycznie różnice występują w przypadku matek w wieku 30-34 lata oraz 35 lat i więcej. Na podstawie zaprezentowanych wyników można zatem sformułować wniosek, iż kobiety, które rozpoczynają starania o dziecko po 30-ym roku życia muszą liczyć się $\mathrm{z}$ istotnym wydłużeniem czasu oczekiwania na ciążę, a co za tym idzie z mniejszą możliwością realizacji zamierzeń prokreacyjnych.

\footnotetext{
7 Istotność statystyczną testowano na poziomie 0,05 .
} 
Zamierzenia prokreacyjne a możliwość ich realizacji w kontekście czynników...

Rys. 4. Czas oczekiwania na ciążę według wieku matki w momencie urodzenia pierwszego dziecka - oszacowanie funkcji dożycia metodą Kaplana-Meier'a

Fig. 4. Waiting time to pregnancy by age of mother at birth of the first child-estimates of survival function by use of the Kaplan-Meier method.

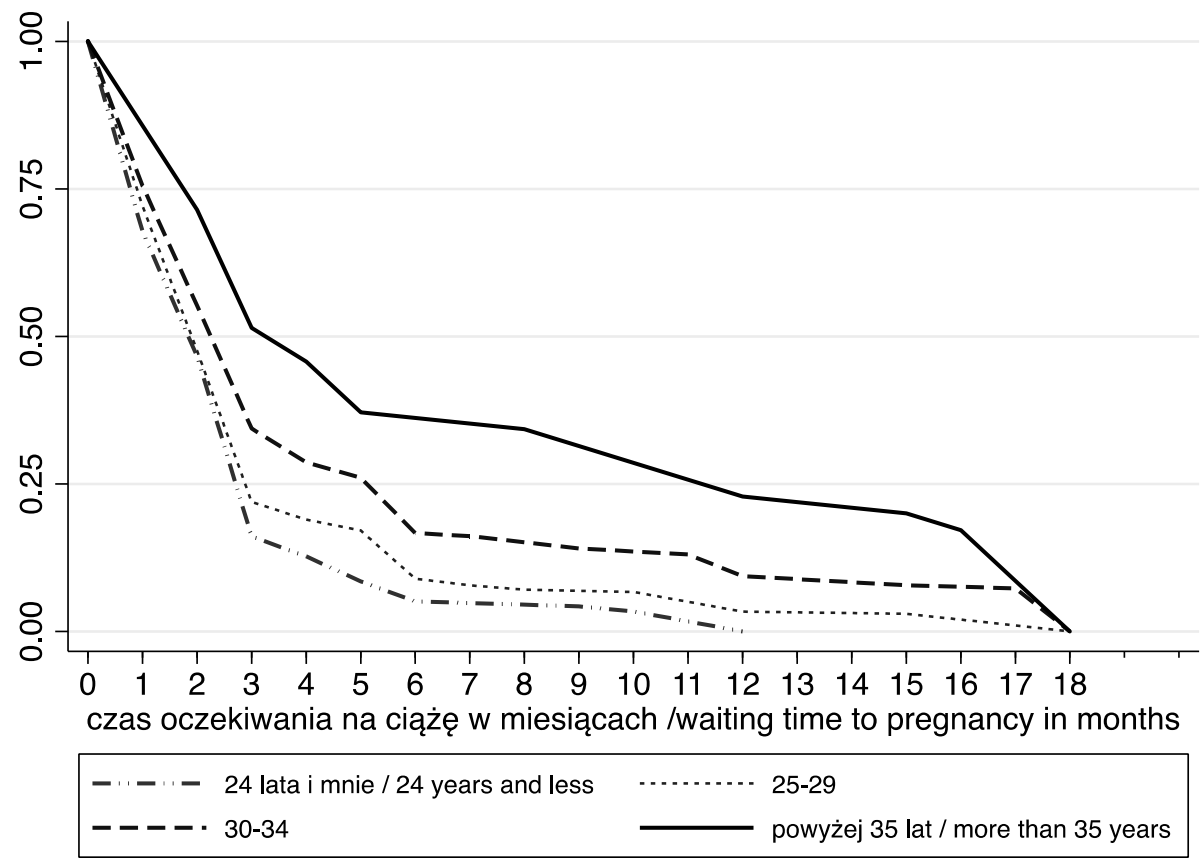

Źródło: obliczenia własne na podstawie badania GGS-PL.

Source: own estimates based on the GGS-PL survey.

Innym zagadnieniem związanym z badaniem okresu oczekiwania na ciążę jest jego długość ze względu na uprzednio stosowaną metodę antykoncepcji. W literaturze istnieją opracowania, w których sformułowano wniosek, iż przyjmowanie antykoncepcji hormonalnej może prowadzić do wydłużenia czasu oczekiwania na ciążę (Farrow i in. 2002; Hassan i Killick 2004, Linn i in. 1982). Analizując dane z badania GGS-PL, nie stwierdzono takiej zależności.

\section{DYSKUSJA WYNIKÓW}

Biorąc pod uwagę powyższe wyniki analiz empirycznych, należy stwierdzić, iż spadek płodności wraz z wiekiem może mieć negatywny wpływ na możliwość realizacji zamierzeń prokreacyjnych. Ten negatywny efekt może być szczególnie znaczący dla kobiet po 35-ym roku życia. Wpływ ten może przejawiać się głównie 
wydłużaniem czasu oczekiwania na ciążę, co w konsekwencji może prowadzić do wzrostu częstości wystąpienia par niedobrowolnie bezdzietnych. Innym istotnym zagrożeniem jest tu późna diagnoza niepłodności i bezpłodności, która może pozostawić mało czasu na interwencję medyczną i tym samym zwiększyć ryzyko niedobrowolnej bezdzietności. Wyniki badań nie pozwalają jednoznacznie stwierdzić, czy opóźnianie wieku rozpoczęcia starań o dziecko może mieć wpływ na dzietność zrealizowaną. Pośrednim wskaźnikiem może być tu odsetek kobiet bezdzietnych mierzony jako stosunek liczby kobiet bezdzietnych w poszczególnych grupach wieku do ogólnej liczby kobiet w kohorcie. $Z$ pewnością jest to miara niedoskonała, gdyż zmiany jej wartości mogą wynikać w głównej mierze z wyboru (bezdzietność dobrowolna), a nie wyłącznie z wynikającego z przyczyn biologicznych braku możliwości realizacji zamierzeń prokreacyjnych.

Analizując dane dotyczące dzietności kohortowej kobiet w wybranych krajach, można zauważyć rosnący odsetek kobiet bezdzietnych w wieku powyżej 30 lat (Human Fertility Database 2013). Jak zostało to zilustrowane na rys. 5, w Polsce odsetek kobiet bezdzietnych w wieku lat 30 w 2001 roku wyniósł blisko $25 \%$ (kohorta urodzona w roku 1971), a w 2009 roku blisko 37\% (kohorta urodzona w roku 1979). Zmiana ta wynika oczywiście z odraczania decyzji o rozpoczęciu starań o dziecko i zarazem pokazuje istotną zmianę zachowań reprodukcyjnych, która może mieć wpływ na możliwość realizacji zamierzeń prokreacyjnych. Równocześnie warto zauważyć, iż wśród kobiet urodzonych w roku 1966 jedynie 15\% pozostało bezdzietnych do wieku 35 lat. Analogiczny odsetek dla kobiet urodzonych w roku 1974 wynosił blisko 22\%. Porównanie odsetka kobiet bezdzietnych w wieku 30 i 35 lat dla obu kohort może świadczyć o tym, iż właśnie w tym okresie wiele z nich decyduje się na rozpoczęcie starań o dziecko.

W przypadku kobiet 40-letnich można przyjąć, iż potencjał prokreacyjny jest na tak niskim poziomie, że większość z nich pozostanie bezdzietna. W 2001 roku około 11\% kobiet 40-letnich nie posiadało potomstwa (kohorta z 1960 roku), a w 2009 roku było to około $15 \%$ (kohorta z 1969 roku). Warto zauważyć, iż kohorta kobiet urodzonych w 1969 roku charakteryzowała się bezdzietnością w wieku 35 lat na poziomie około $17 \%$ (w roku 2005). Pokazuje to, że jedynie niewielki odsetek kobiet poczyna i rodzi dziecko między 35-tym a 40-tym rokiem życia. Można zatem przypuszczać, iż bezdzietność w wieku 40 lat wskazuje przybliżony odsetek kobiet, które pozostaną bezdzietne aż do końca życia. Jak widać na rys. 5, odsetek ten wykazywał w latach 2001-2009 tendencję rosnącą, jednak tempo przyrostu było wolniejsze niż w przypadku pozostałych grup wieku. Rosnący odsetek kobiet bezdzietnych wynika w dużej mierze ze zmiany indywidualnego nastawienia do formowania rodziny i posiadania dzieci, która przejawia się w odraczaniu decyzji prokreacyjnych. W świetle zaprezentowanych wyników może to prowadzić do pojawienia się problemów z zajściem $\mathrm{w}$ ciążę z powodu spadku potencjału prokreacyjnego wraz z wiekiem bądź zbyt późnej diagnozy niepłodności. 
Zamierzenia prokreacyjne a możliwość ich realizacji w kontekście czynników...

Rys. 5. Odsetek kobiet bezdzietnych w wieku 30, 35 i 40 lat w Polsce, 2001-2009

Fig. 5. Percentage of childless women at age 30, 35 and 40 years in Poland, 2001-2009.

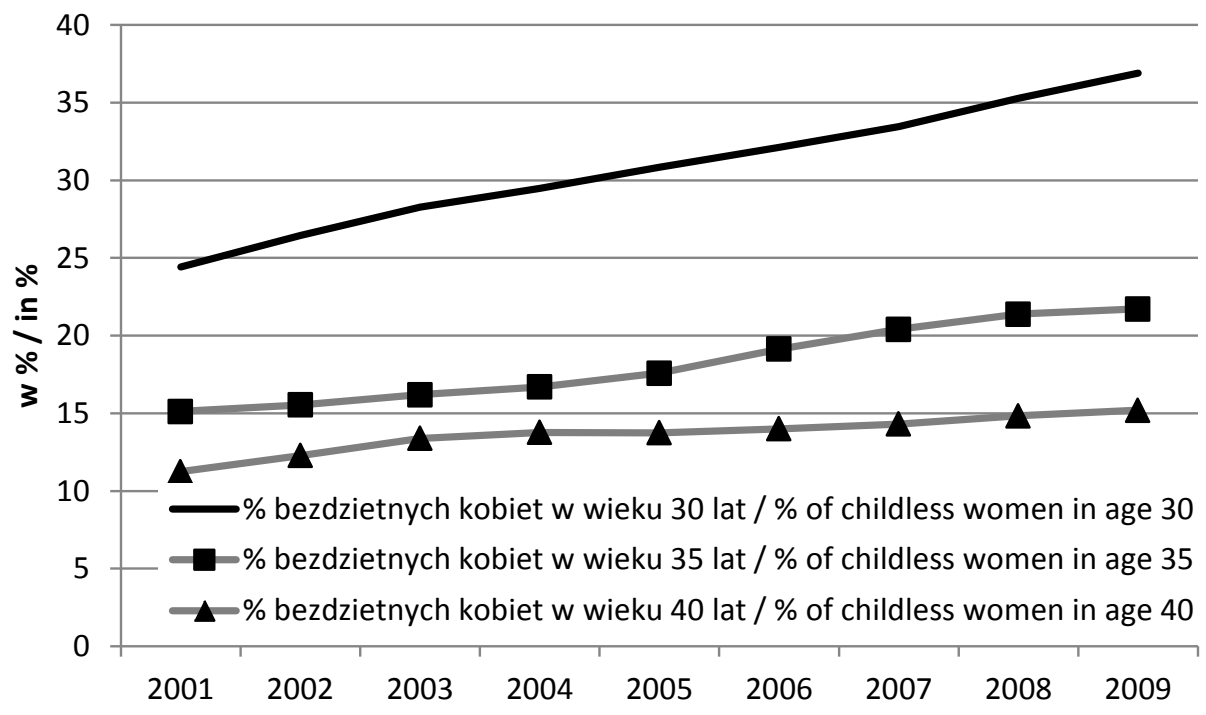

Źródło: obliczenia własne na podstawie danych z rejestracji urodzeń GUS.

Source: own estimates based on the population register of Poland.

Obserwując trendy proporcji kobiet bezdzietnych w wybranych krajach, można zaobserwować znaczące zróżnicowanie udziału bezdzietnych kobiet w wieku lat 40 w kohorcie z 1969 roku wybranych krajach (Rys. 6).

W Bułgarii jedynie około 5\% kobiet w wieku lat 40 było bezdzietnych, podczas gdy w Japonii odsetek ten wyniósł aż 27\%. Z punktu widzenia analiz zaprezentowanych w artykule, można zastanawiać się na ile zaobserwowana bezdzietność wynika z bezpłodności lub niepłodności, a na ile wynika ona z indywidualnych decyzji dotyczących rezygnacji z macierzyństwa. Jednoznaczna odpowiedź na to pytanie może być trudna, lecz porównując odsetki kobiet bezdzietnych w wieku lat $40 \mathrm{w}$ obu krajach należy przypuszczać, iż w Japonii dużo częściej wynika ona $\mathrm{z}$ decyzji indywidualnych. 
Rys. 6. Odsetek kobiet bezdzietnych w wieku 40 lat z kohorty z 1969 roku w wybranych krajach

Fig. 6. Percentage of childless women at age 40 years, birth cohort 1969, selected countries

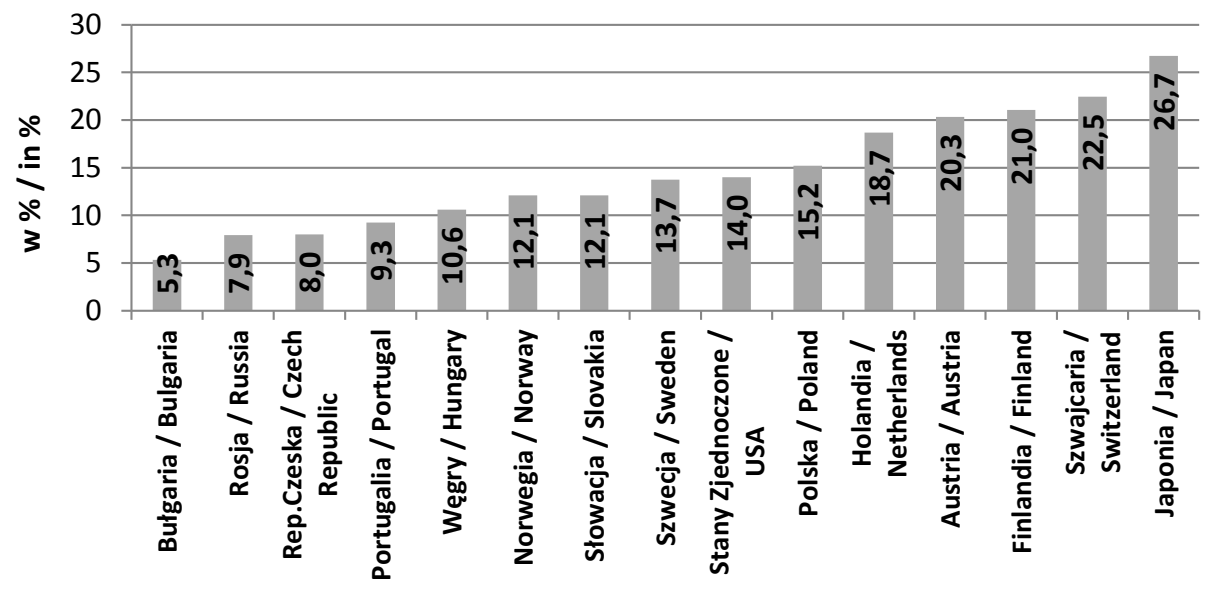

Źródło: obliczenia własne na podstawie Human Fertility Database (2013) oraz rejestracji urodzeń GUS.

Source: own estimates based on the Human Fertility Database (2013) and the population register of Poland.

\section{PODSUMOWANIE}

Oprócz omawianej wyżej kwestii, na ile zaobserwowana bezdzietność kobiet wynika z bezpłodności lub niepłodności, a w jakim stopniu można ją przypisać rezygnacji z macierzyństwa, istotne jest też pytanie, w jaki sposób poziom bezdzietności wpływa na ogólny poziom dzietności zrealizowanej. Czy w krajach o wysokiej proporcji kobiet bezdzietnych obserwujemy niższe wskaźniki dzietności kohortowej? Czy też może proporcja ta nie ma wpływu na wartość wskaźników na poziomie populacji z uwagi na fakt, iż kobiety posiadające dzieci decydują się na taką ich liczbę, która kompensuje wysoki poziom bezdzietności? Rysunek 7 pokazuje, że niski poziom dzietności zrealizowanej nie zawsze współwystępuje z wysokim odsetkiem kobiet bezdzietnych. W takich krajach jak Bułgaria Portugalia, czy Rosja dzietność zrealizowana mieści się w przedziale od 1,58 do 1,7 (w krajach tych około $80 \%$ kobiet posiada jedno bądź dwoje dzieci), przy najniższym z zarejestrowanych odsetku kobiet bezdzietnych wynoszącym mniej niż 10\%. Dla porównania, takie kraje jak Austria, Japonia ${ }^{8}$ czy Szwajcaria mają jeden z najwyższych udziałów kobiet bezdzietnych (około 20\%) przy porównywalnym poziomie dzietności zrealizowanej

8 W Japonii około 57\% kobiet posiada jedno lub dwoje dzieci a $16 \%$ troje lub czworo. 
(około 1,6). Pozostałe kraje wykazują umiarkowany odsetek kobiet bezdzietnych przy dzietności zrealizowanej powyżej średniej (Czechy, Norwegia, Polska, Słowacja, Szwecja, USA, Węgry) ${ }^{9}$. Wyjątkiem jest tu Finlandia, gdzie - przy relatywnie wysokim odsetku kobiet bezdzietnych do 40 roku życia (21\%) - obserwujemy relatywnie wysoką dzietność zrealizowaną (prawie 30\% kobiet posiada trójkę lub czwórkę dzieci).

Rys 7. Dzietność zrealizowana w ujęciu kohortowym do 40-tego roku życia oraz odsetek kobiet bezdzietnych w wieku 40 lat, kohorta kobiet z 1969 roku, wybrane kraje*

Fig. 7. Completed fertility up to age 40 years and the percentage of childless women at age 40 years, birth cohort 1969, selected countries*

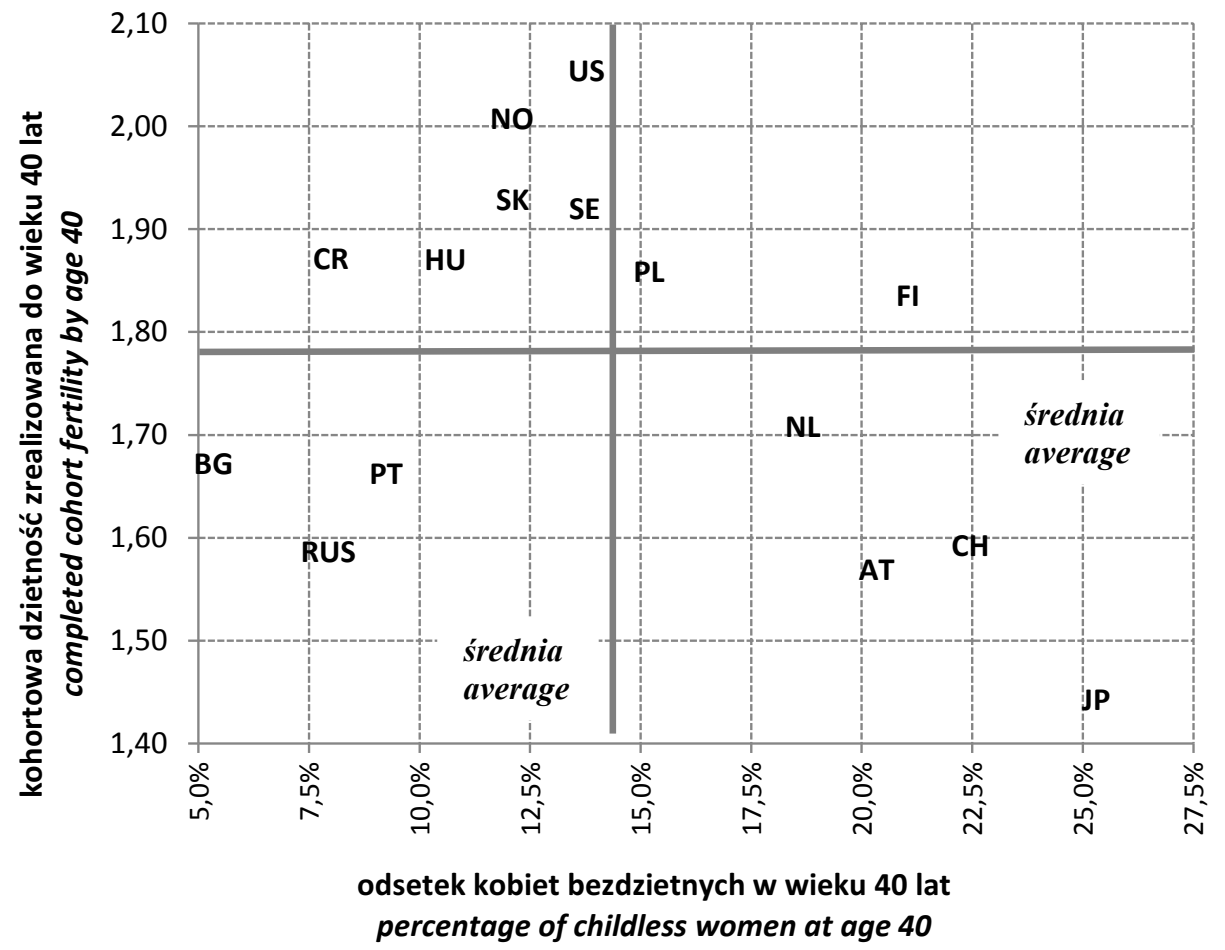

* Linie oznaczają wartości średnie dla wybranych krajów.

* Lines indicate the mean value for selected countries.

Źródło: obliczenia własne na podstawie Human Fertility Database (2013) oraz rejestracji urodzeń GUS.

Source: own estimates based on the Human Fertility Database (2013) and the population register of Poland.

9 W USA, kraju o najwyższym współczynniku dzietności kohortowej do 40 roku życia wynoszącym 2,06, obserwujemy jedynie 13\% kobiet bezdzietnych, jedno dziecko posiada jedynie $19 \%$ kohorty, dwoje lub troje blisko 55\%, a czworo lub więcej blisko $13 \%$. 
Struktura kohort kobiet względem liczby urodzeń w oczywisty sposób wpływa na dzietność zrealizowaną w wymiarze kohortowym. Kluczowym czynnikiem jest tu wiek rozpoczęcia starań o dziecko, gdyż biorąc pod uwagę spadek potencjału prokreacyjnego wraz z wiekiem rozpoczęcie starań może prowadzić do niechcianej niepłodności. Co więcej, późne urodzenie pierwszego dziecka może utrudnić poczęcie kolejnych dzieci i mieć negatywny wpływ na dzietność zrealizowaną w poszczególnych kohortach.

Istotną kwestią jest tu określenie, czy we współczesnych krajach rozwiniętych, a więc tych charakteryzujących się wysokim średnim wiekiem rodzenia pierwszego dziecka, ogólny poziom dzietności może się obniżać z powodu rozbieżności między decyzjami prokreacyjnymi a zmianami płodności. Według danych OECD średni wiek rodzenia pierwszego dziecka jest najwyższy w takich krajach jak Wielka Brytania, Niemcy, Hiszpania, Włochy, Szwajcaria, Korea i Japonia (około 30 lat) przy czym. przyrosty wartości tego wskaźnika nie są już tak dynamiczne jak jeszcze 10 lub 15 lat temu ${ }^{10}$. Może to świadczyć o tym, że proces opóźniania decyzji o posiadaniu dziecka osiągnął swój kres. Należy oczywiście pamiętać, iż jest to wartość dla całej populacji i można spodziewać się, iż w pewnych grupach społecznych starania o pierwsze dziecko mogą rozpoczynać się jeszcze później, a co za tym idzie problemy związane z poczęciem dziecka mogą być większe. W celu określenia skali zagrożenia brakiem możliwości realizacji intencji prokreacyjnych wynikających z opóźniania decyzji należałoby przeprowadzić szczegółowe analizy w poszczególnych grupach wyodrębnionych ze względu na zmienne wpływające na opóźnianie decyzji o posiadaniu dziecka. Interpretując dane dotyczące zmian odsetka bezdzietnych kobiet należy pamiętać, iż mogą one wynikać również ze wzrostu liczby osób świadomie rezygnujących z posiadania dzieci, a nie być jedynie konsekwencją spadku płodności wraz z wiekiem.

Ze względu na opisowy charakter analiz otrzymane wyniki mogą posłużyć do dalszych pogłębionych studiów. Interesującym kierunkiem badań wydaje się analiza rozbieżności między biologicznym wzorcem płodności a zachowaniami prokreacyjnymi w wybranych grupach społecznych. Jak wiadomo, przesuwanie się przeciętnego wieku urodzenia pierwszego dziecka poza wiek maksymalnej płodności, czyli 20-22 lata, może prowadzić do pojawienia się problemów z zajściem w ciążę. Dzietność odroczona na lata późniejsze może nie zostać „odzyskana” podczas starania się o dziecko w późniejszym wieku. Taki mechanizm niekompletnego przełożenia się dzietności planowanej na dzietność zrealizowaną może mieć niebagatelne znaczenie dla kształtowania się ogólnego poziomu dzietności w populacji. Biorąc pod uwagę niski poziom ogólnego współczynnika dzietności w Polsce, należy zwrócić szczególną uwagę na wpływ decyzji o odraczaniu decyzji o posiadaniu dziecka na możliwość realizacji zamierzeń prokreacyjnych.

10 OECD Family Database, zasób internetowy, http://www.oecd.org/els/soc/ (data dostępu: wrzesień 2013). 
Jak sugeruje wielu autorów (Leridon 2004, Schmidt i in. 2012), duże znaczenie może odegrać akcja informacyjna nakierowana na uświadomienie bio-medycznych konsekwencji odraczania decyzji o dziecka. Taka akcja informacyjna umożliwiła nie tylko uświadomienie konsekwencji, ale także mogłaby przyczynić się do zmian postaw i zachowań prokreacyjnych.

\section{LITERATURA}

Baird D.D.,Weinberg C.R., Rowland A.S.,1991, Reporting errors in Time-to-Pregnancy data collected with a short questionnaire, „American Journal of Epidemiology”, vol. 133, nr 12, 1282-1290.

Beets G., teVelde E., Verloove-Vanhorick P., Merkus H., Bruinse H., 1994, MedicalComplications of Aging Fertility, [w:] G. Beets, (red.), Population and Family in the Low Countries 1993: Late Fertility and Other Current Issues (s. 1-23), NIDI/CBGS Publication, Berwyn, Pennsylvania/ Amsterdam, Netherlands.

Bianchi F.O., Campana A.,1994, The end of fertility: age, fecundity and fecundability in women, „Journal of Biosocial Science”, vol. 26, nr 3, 349-368.

Boldsen J.L., Schaumburg I., 1990, Time to pregnancy: A model and its applications, „Journal of Biosocial Science", vol. 22, nr 2, 255-262.

Bongaarts J., 1978, A framework for analysing the proximate determinants of fertility, „Population and Development Review", vol. 4, nr 1, 105-132.

Bongaarts J., 1990, The Measurement of Wanted Fertility, „Population and Development Review”, vol. 16 , $\mathrm{nr} 3,487-506$.

Bongaarts J., 2002, The end of the fertility transition in the developed world, „Population and Development Review", vol. 28, nr 3, 419-433.

Bongaarts J., Feeney G., 1998, On the Quantum and Tempo of Fertility, „Population and Development Review", vol. 24, nr 2, 271-291

Dick M.L.B, Bain C.J., Purdie D.M., Siskind V., Molloy D., Green A.C., 2003, Self-reported difficulty in conceiving as a measure of infertility, „Human Reproduction”, vol. 18, nr 2, 2711-2717.

ESHRE, 2005, Human Reproduction Update, „Fertility and Ageing. Capri Workshop Group”, vol. 11, nr 3, 261-276.

Farrow A., Hull M.G.R., Northstone K., Taylor H.F., Ford W.C.L., Golding J., 2002, Prolonged use of oral contraception before a planned pregnancy is associated with a decreased risk of delayed conception", „Human Reproduction”, vol. 17, nr 10, 2754-2761.

Gnoth C.G., Frank-Herrmann E., Friol1 P., Tigges K., Freundl J., 2005, Definition and prevalence of subfertility and infertility, „Human Reproduction”, vol. 20, nr 5, 1144-1147.

Habbema J.D.F., Collins J., Leridon H., Evers J.L.H., Lunenfeld B., teVelde E.R., 2004, Towards less confusing terminology in reproductive medicine: a proposal, „Human Reproduction”, vol. 19, nr 7,1501 .

Hassan M.A.M., Killick S.R., 2004, Is previous use of hormonal contraception associated with a detrimental effect on subsequent fecundity?, „Human Reproduction”, vol. 19, nr 2, 344-351.

Hawkes K., 2003, Grandmothers and the evolution of human longevity, „American Journal of Human Biology", vol. 15, nr 3, 380-400.

Hill K.A., Hurtado M., 1991, The evolution of premature reproductive senescence and menopause in human females, „Human Nature”, vol. 2, nr 4, 313-350.

Human Fertility Database, 2013, zasób internetowy, www.humanfertility.org (data dostępu 10.05.2013).

O’Connor K.A., Holman D.J., Wood J.W., 1998, Declining fecundity and ovarian ageing in natural fertility populations, „Maturitas”, vol. 30, nr 2, 127-136.

Jenkins J., Daya S., Kremer J., Balasch J., Barratt C., Cooke I., Lawford-Davies J., De Sutter P., Suikari A.M., Neulen J., Nygren K., 2004, European Classification of Infertility Taskforce (ECIT). Response 
to Habbema 'Towards less confusing terminology in reproductive medicine: a proposal', „Human Reproduction", vol. 19, nr 12, 2687-2688.

Jensen T.K., Joffe M., Scheike T., Skytthe A., Gaist D., Christensen K., 2005, Time Trends in Waiting Time to Pregnancy Among Danish Twins, „Human Reproduction”, vol. 20, nr 4, 955-964.

Joffe M., Key J., Best N., Keiding N., Scheike T., Jensen T.K., 2005, Studying Time to Pregnancy by Use of a Retrospective Design, „American Journal of Epidemiology”, vol. 162, nr 2, 115-124.

Kaplan H., Hill K., Lancaster J., Hurtado A.M., 2000, A theory of human life history evolution: diet, intelligence, and longevity, ,„Evolutionary Anthropology”, vol. 9, nr 4, 156-185.

Karmaus W., Juul S., 1999, Infertility and subfecundity in population-based samples from Denmark, Germany, Italy, Poland and Spain, „, European Journal of Public Health”, vol. 9, nr 3, 229-235.

Kohler H-P, Billari F.C., Ortega J.A., 2002, The Emergence of Lowest-Low Fertility in Europe During the 1990s, „Population and Development Review”, vol. 28, nr 4, 641-680.

Kotowska I.E., Jóźwiak J., 2011, Panelowe badanie przemian relacji między pokoleniami, w rodzinie oraz między kobietami i mężczyznami: Generacje, Rodziny i Płeć Kulturowa GGS-PL, „Studia Demograficzne", nr 1/159, 99-106.

Leridon H., 2004, Can assisted reproduction technology compensate for the natural decline in fertility with age? A model assessment, „Human Reproduction”, vol. 19, nr 7, 1548-1553.

Liu K., Case A., 2011, Advanced reproductive age and fertility, „Journal of Obstetrics and Gynaecolgy”, vol. 33, nr 11, 1165-1175.

Linn S., Schoenbaum S.C., Monson R.R., Rosner B., Ryan K.J., 1982, Delay in conception for former 'pill' users, „The Journal of the American Medical Association“, vol. 247, nr 5, 629-632.

Mynarska M., 2011, Kto planuje mieć dzieci w Polsce do 2015 roku?, „Studia Demograficzne”, nr 1/159, 75-98.

Olsen J., Juul S., Basso O., 1998, Measuring time to pregnancy. Methodological issues to consider, „Human Reproduction“, vol. 13, nr 7, 1751-1753.

ORC Macro and the World Health Organization, 2004, Infecundity, infertility, and childlessness in developing countries, "Demographic and Health Surveys (DHS) Comparative Reports", 9.

Régnier-Loilier A., Vignoli D., 2011, Fertility Intentions and Obstacles to Their Realization in France and Italy, „Population”, vol. 66, nr 2, 361-389.

Sartorius G.A., Nieschalg E., 2010, Paternal Age and Reproduction, „Human Reproduction Update”, vol. $16, \mathrm{nr} 1,65-79$.

Schmidt L., Sobotka T., Bentzen J.G., Nyboe A.A., 2012, Demographic and Medical Consequences of the postponement of parenthood, „Human Reproduction Update”, vol. 18, nr 1, 29-43.

Shanley D.P., Kirkwood T.B.L., 2001, Evolution of the human menopause, „BioEssays”, vol. 23, nr 3, 282-287.

Sobotka T., 2007, The diverse faces of the Second Demographic Transition in Europe, „Demographic Research", vol. 19, nr 8, 171-224.

Sobotka T., Lutz W., Phillipov D., 2005, Missing Births: Decomposing the Declining Number of Birts in Europe into Tempo, Quantum and Age Structure Effects, „European Demographic Research Papers", Vienna Institute of Demography, 2.

Sobotka T., Zeman K., Lesthaeghe R., Frejka T., Neels K., 2011, Postponement and Recuperation in Cohort Fertility: Austria, Germany and Switzerland in a European Context, „Contemporary Population Studies", vol. 36, nr 2-3, 417-452.

Testa M.R., 2012, Women's fertility intentions and level of education: why are they positively correlated in Europe?, „European Demographic Research Papers”, 3, Vienna Institute of Demography of the Austrian Academy of Sciences, Vienna.

teVelde E. R., Habbema D., Leridon H., Marinus E., 2012, The effect of postponement of first motherhood on permanent involuntary childlessness and total fertility rate in six European countries since the 1970s, „Human Reproduction”, vol. 27, nr 4, 1179-1183

teVelde E.R., Pearson P.L., 2002, The variability of female reproductive ageing, „Human Reproduction Update“, vol. 8, nr 2, 141-154. 
Zamierzenia prokreacyjne a możliwość ich realizacji w kontekście czynników...

Toulemon L., Testa M.R., 2005, Fertility intentions and actual fertility: a complex relationship, „Population and Societies”, nr 415, 1-4.

Van Geloven N.F., Van der Veen P.M.M., Bossuyt P.G., Hompes A.H., Zwinderman B.W. Mol B.W., 2013, Can we distinguish between infertility and subfertility when predicting natural conception in couples with an unfulfilled child wish?, „Human Reproduction”, vol. 28, nr 3, 658-665.

Wood J.W. 1989, Fecundity and Natural Fertility in Humans, [w:] S.R. Milligan (red.) Oxford Reviews of Reproductive Biology (s. 61-109), Oxford University Press, Oxford.

Zegers-Hochschild F., Adamson G.D., de Mouzon J., Ishihara O., Mansour R., Nygren K., Sullivan E., van der Poel S., 2009, The International Committee for Monitoring Assisted Reproductive Technology (ICMART) and the World Health Organization (WHO) Revised Glossary on ART Terminology, "Human Reproduction", vol. 24, nr 11, 2683-2687.

\title{
REALISATION OF FERTILITY INTENTIONS IN THE CONTEXT OF BIOLOGICAL FACTORS
}

\begin{abstract}
The article presents both theoretical and empirical aspects of studies on fertility intentions in the context of factors shaping fecundity. In most contemporary societies couples declare their preference for two children. These declarations stand in opposition to registered total fertility rates, both period and cohort rates, which rarely reach value of 2 in Europe. The gap between fertility intentions and their realization might be partially explained by the impact of reproductive ageing (biological factors) which may play an increasingly significant role due to postponement of childbearing. A natural pattern of a decrease in fecundity over age might influence on reproductive outcome of women who postpone to conceive a child, and consequently results in an increased risk of involuntary childlessness or lower parity progression ratios. The data coming from the Generations and Gender Survey in Poland (GGS-PL) makes it possible to check the main hypothesis about an age-specific decrease in fecundity, which is manifested by a prolonged waiting time to pregnancy. The data were collected via the retrospective questions included into the GGS-PL questionnaire. Results show that there is a significant increase in waiting time to pregnancy among women older than 34 years. This finding supports theoretical predictions concerning the age-related decrease in fecundity. Its relevance is discussed by referring to explanations of the gap between fertility intentions and completed fertility in terms of voluntary and involuntary childlessness, as well as biological factors related to reproductive ageing.
\end{abstract}

Keywords: reproductive ageing, fecundity, waiting time to pregnancy, infertility, fertility. 